\title{
EFFECT OF ADDITION OF WILD GARLIC (ALLIUM URSINUM) ON THE QUALITY OF KEFIRS FROM SHEEP'S MILK
}

\author{
Agata Znamirowska ${ }^{1 凶}$, Katarzyna Szajnar ${ }^{1}$, Przemysław Rożek ${ }^{1}$, Dorota Kalicka ${ }^{1}$, \\ Piotr Kuźniar³, Paweł Hanus², Krzysztof Kotula², Marcin Obirek², Maciej Kluz ${ }^{4}$ \\ ${ }^{1}$ Department of Dairy Technology, University of Rzeszów \\ Ćwiklińskiej 2D, 35-601 Rzeszów, Poland \\ 2Student Scientific Group of Food Technologist FERMENT, University of Rzeszów \\ Ćwiklińskiej 2, 35-601 Rzeszów, Poland \\ ${ }^{3}$ Department of Food and Agriculture Production Engineering, University of Rzeszów \\ Zelwerowicza 4, 35-601 Rzeszów, Poland \\ ${ }^{4}$ Department of Biotechnology and Microbiology, University of Rzeszów \\ Ćwiklińskiej 2, 35-601 Rzeszów, Poland
}

\begin{abstract}
Background. Sheep's milk has a high content of total solids, which qualifies it as a very good raw material for the production of fermented milk drinks. Currently, there are commercially produced kefirs and yogurts from sheep's milk in the countries of the Mediterranean region. The growing interest in the consumption of these products is justified not only by their taste merits, but also because of their health-promoting properties. The aim of the present study was to determine the effect of the addition of $1 \%$ of lyophilized wild garlic powder on the properties of kefirs from sheep's milk.

Material and methods. Sheep's milk was pasteurized $\left(85^{\circ} \mathrm{C}, 30 \mathrm{~min}\right)$, cooled down, enriched with $1 \%$ of freeze-dried wild garlic powder, inoculated with a Commercial VITAL kefir culture and fermented for 16 hours $\left(26^{\circ} \mathrm{C}\right)$. The influence of wild garlic on acidity $\left(\mathrm{pH},{ }^{\circ} \mathrm{SH}\right)$, syneresis $(\%)$, texture (TPA test), colour $\left(\mathrm{L} * \mathrm{a}^{*} \mathrm{~b}\right)$ and the sensory profile of kefirs was conducted.

Results. Wild garlic could be used as a taste and flavour modifier in the production of kefir from sheep's milk. The addition of $1 \%$ of freeze-dried wild garlic slowed down the fermentation of kefir, changed colour and reduced syneresis.

Conclusions. Wild garlic could be used as a valuable supplement and a modifier of taste and flavour in kefir from sheep's milk.
\end{abstract}

Keywords: kefir, wild garlic, sheep's milk

\section{INTRODUCTION}

Kefirs are popular fermented milk drinks in Poland. They are most frequently produced from cow's and goat's milk, rarely from sheep's milk. This is due to the low production and seasonal nature of obtaining sheep's milk. Currently, there are commercially produced kefirs and yogurts from sheep's milk in the countries of the Mediterranean area (Bonczar and Wszołek, 1997). The growing interest in the consumption of these products is justified not only by their taste qualities, but also because by their health benefits (Bonczar et al., 1995).

凶aznam@ur.edu.pl 
Sheep's milk has a high content of total solids, which qualifies it as a very good raw material for the production of fermented milks. In the manufacture of fermented sheep's milk there is no need to regulate the solid-not-fat (SNF) level with dairy powders, which is usually performed in standard production from cow's milk (Danków and Pikul, 2011). There has been relatively little research carried out on sheep milk kefirs, especially in Poland. Bonczar and Wszołek (1997) assessed the quality and durability of kefirs from sheep's milk coming from the Małopolska region. Moreover, Cais-Sokolińska et al. (2008) wrote about changes in the physicochemical and sensory properties of sheep kefir during storage. The profile of fatty acids in kefirs from sheep's milk was also studied by Wójtowski et al. (2003). Danków et al. (2000) studied the effect of starter cultures and storage time on the quality factors of sheep milk kefirs.

Milk and milk products belong to the group of food which are often fortified with micro- and macro-elements, fibres, vitamins and other active compounds. Enrichment of milk drinks has become accepted and appreciated by consumers. The taste and aroma of kefir produced by acidic-alcoholic fermentation could produce a good combination with the addition of herbs and vegetables. Moreover, kefirs, buttermilks and other fermented milks are good components for the preparation of cold fruit or vegetable soups.

Several studies have shown that wild garlic and its bioactive compounds can be used in the prevention of many diseases, e.g. of the cardiovascular system (atherosclerosis, myocardial infarction, high blood pressure), cancers, and of bacterial, viral and fungal diseases with a strong bactericidal effect (Bat-Chen et al., 2010; Durak et al., 2004), hence the concept of enriching kefir from sheep's milk with wild garlic coming from the Podkarpackie region. Therefore, the aim of the research was to determine the effect of adding $1 \%$ of freeze-dried wild garlic powder on the properties of kefirs from sheep's milk.

\section{MATERIAL AND METHODS}

\section{Materials}

Sheep's milk was purchased in June 2015 from the farm "Owcza Zagroda" (Wyżne, Poland). A flock of 35 Olkuska breed sheep were kept on the farm.Green fodder and hay with addition of cereals (oats, barley and maize in a quantity of $0.5 \mathrm{~kg} / \mathrm{sheep} /$ day) from the breeder's own farm were used for feeding animals. Milking was done by hand. Wild garlic (Allium ursinum) was collected in May 2015 on a farm in Dukla, Podkarpackie region, where wild garlic is cultivated on a 1 ha meadow in conditions similar to natural ones. The meadow is mowed once a year, animals are not grazed there, nor are fertilizer or pesticides used. To manufacture kefir a Kefir VITAL (Danisco-Dupont, Poland) starter culture was used. The VITAL series comprises starter cultures in sachets dedicated for home production of fermented dairy products. According to the producer's specifications, one sachet contains the correct amount of kefir grains (kefir yeast and lactic acid bacteria Leuconostoc subsp., Lactococcus lactis subsp., Streptococcus thermophilus, Lactobacillus acidophilus) to prepare 1-3 liters of kefir, which is also optimal for agritourism needs. The chemical composition (fat, protein, lactose, total solids) and freezing point of sheep's milk were determined using the Milk Analyzer B-150 (Bentley Instruments, USA). The total number of microorganisms and the somatic cell count were determined using BactoCount IBC-m/ SCC (Bentley Instruments, USA).

\section{Manufacture of kefirs}

The leaves of the wild garlic were washed in boiled and cooled water, then dried with tissue paper and subequently frozen in a commercial freezer $\left(-22^{\circ} \mathrm{C}\right)$. Lyophilization was processed in the Christ ALPHA 1-2 LD plus freeze-dryer (Martin Christ $\mathrm{GmbH}$, Germany). Milk was pasteurized $\left(85^{\circ} \mathrm{C}, 30 \mathrm{~min}\right)$ and cooled down to $26^{\circ} \mathrm{C}$. The lyophilized leaves of garlic were ground into a powder in a mortar, then weighed and added to the milk in an amount of $1 \%$. To determine the level of wild garlic to be added, a pre-study of preferences was made using a dose of $0.5 \%, 1 \%, 1.5 \%, 2 \%$ and $3 \%$, respectively. The evaluators most preferred kefirs with a $1 \%$ garlic addition (unpublished data). One sachet of Kefir VITAL was added to 31 of pasteurized and cooled milk supplemented with wild garlic. A control sample was made without the addition of garlic. Then the milk was poured into containers with a capacity of $100 \mathrm{ml}$ with a lid and fermented for 16 hours at a temperature of $26^{\circ} \mathrm{C}$. The kefirs were cooled down to $8^{\circ} \mathrm{C}$ and stored at this temperature for 7 days. 


\section{Analyses of the kefirs}

On the seventh day of cold storage an assessment of quality was carried out. The active acidity $(\mathrm{pH})$ of milk and kefir was determined with the $\mathrm{pH}$-meter FiveEasy (Mettler Toledo, Switzerland). The titratable acidity of milk $\left({ }^{\circ} \mathrm{SH}\right)$ was established by the Soxhlet-Henkel method, while the titratable acidity in kefir was expressed in \% of lactic acid (Litwińczuk et al., 2011). Syneresis was determined by weight, as a percentage leakage of whey from $25 \mathrm{~g}$ of the sample after $2 \mathrm{~h}$, at a temperature of $5^{\circ} \mathrm{C}$ (Znamirowska et al., 2016). The texturometric profile was determined by the TPA test using a CT3 Texture Analyzer (Brookfield, USA) with Texture Pro CT (Brookfield, USA) software. The sample dimensions were cylinder $66 \mathrm{~mm} \times 33.86 \mathrm{~mm}$ and the temperature of the sample was $8^{\circ} \mathrm{C}$. The test was performed using the acrylic probe TA $3 / 100$ and the following settings: distance $15 \mathrm{~mm}$, contact load $0.1 \mathrm{~N}$, measurement speed $1 \mathrm{~mm} / \mathrm{s}$ (Znamirowska et al., 2016). The parameters of $L^{*}, a^{*}, b^{*}$ colours were determined with the Konica Minolta Chroma Meter CR-410 colorimeter, using the CIELAB method. The image brightness was determined with the parameter $\mathrm{L}^{*}$, and chromaticity with the use of the parameters $a^{*}$ and $b^{*}$. Before testing, the device was calibrated on a white reference standard. The assessment of kefir with the method of sensory profiling (PN-ISO 11035:1999) was carried out by tahe team of 12 persons of proven sensory sensitivity. The samples of kefir were assessed on a $9 \mathrm{~cm}$ linear scale, non-structured, with markings at both ends. The left end denoted the least perceptible feature and the right end denoted the most intense, the most characteristic feature. The following descriptors were studied: consistency, $\mathrm{CO}_{2}$ saturation, colour, taste (yeasty, sour, garlic, off-flavours), aroma (of fermentation, strange, garlic). Preferences were rated with the ranking method, where position 1 denoted the most preferred yogurt, and position 3 the least preferred drink (Baryłko-Pikielna and Matuszewska, 2014).

The experiment was repeated three times, each parameter was measured five times. From the data obtained the mean and the standard deviation were calculated using Statistica v. 12 software. The significance of differences between the groups was determined by Tukey's test at $p \leq 0.05$.

\section{RESULTS AND DISCUSSION}

Table 1 shows the physicochemical properties of sheep's milk used for the production of kefir. The average protein, fat, lactose and total solid contents were comparable to the results reported in the literature (Bonczar et al., 2002; 2009; Cais-Sokolińska et al., 2008; Vivar-Quintana et al., 2006). The $\mathrm{pH}$ value determined in the tests was higher than that shown by Vivar-Quintana et al. (2006) who marked a pH in sheep's milk from 6.6 to 6.8 , depending on the content of somatic cells. Sheep's milk analyzed by Bonczar et al. (2002) had a lower pH value (6.66) and a lower titratable acidity $\left(11.2^{\circ} \mathrm{SH}\right)$ than that shown in Table 1. In other studies Bonczar and Reguła (2003) marked a $\mathrm{pH}$ of 6.63 and a titratable acidity of $18.8^{\circ} \mathrm{SH}$ in sheep's milk. Awassi ewes' milk in the studies by Şahan et al. (2005) was characterized by a $\mathrm{pH}$ of 6.21 to 7.29 , depending on the time within 18 months of lactation. In contrast, fresh sheep's milk used by Katsiari et al. (2002) for the production of yoghurt had a lower $\mathrm{pH}$ (6.53) than that found in the studies conducted.

Table 1. Parameters of fresh sheep's milk used in the manufacture of kefirs

\begin{tabular}{lr}
\hline Protein, \% & $5.34 \pm 0.22$ \\
Fat, \% & $6.09 \pm 1.02$ \\
Lactose, \% & $5.01 \pm 0.12$ \\
Total solid, \% & $17.61 \pm 0.57$ \\
pH & $6.85 \pm 0.12$ \\
Titratable acidity, ${ }^{\circ} \mathrm{SH}$ & $12.81 \pm 1.02$ \\
Freezing point, ${ }^{\circ} \mathrm{C}$ & $-0.623 \pm 0.07$ \\
Total bacterial counts, $\mathrm{CFU} / \mathrm{ml}$ & $489290.12 \pm 21.31$ \\
Somatic cells count in $1 \mathrm{ml}$ & $55.000 \pm 1414.21$ \\
\hline
\end{tabular}

Values are means \pm standard deviation.

The total bacterial counts (TBC) in the sheep's milk analyzed did not exceed 500000 CFU in $1 \mathrm{ml}$. In accordance with the Regulation of the European Parliament and Council No. 853/2004, it could be used for the production of milk products even without heat 
treatment. Králíčková et al. (2012) also reported that the values of TBC for sheep's milk collected at different stages of lactation did not exceed $1.5 \times 10^{6} \mathrm{CFU}$ per $1 \mathrm{ml}$, which is the maximal limit of TBC for raw sheep's milk. In milk of sheep from Kosovo Bytyqi et al. (2013) marked a TBC from $1211.17 \mathrm{CFU} / \mathrm{ml}$ to 6425.76 CFU/ml. Alexopoulos et al. (2011) studied the milk of sheep from the north-eastern Greece and indictaed the total bacterial counts at the level of $3 \times$ $10^{5} \mathrm{CFU} / \mathrm{ml}$.

Table 2 shows the results of $\mathrm{pH}$, acidity, colour and syneresis of natural kefir and kefir with the addition of wild garlic powder. In kefir with wild garlic powder there was a significantly higher $\mathrm{pH}$ value and a lower lactic acid content [\%] than in the control kefir. The differences in the acidity of kefirs could be the result of the antimicrobial activity of wild garlic. According to the literature, Allium ursinum shows the antibacterial effect on the bacteria gram $(+)$ and the bacteria gram $(-)$ (Sapunjieva et al., 2012; Stajner et al., 2008). Sulphur compounds are mainly responsible for the biological activity of wild garlic (Dżugan et al., 2014; Radulović et al., 2015). It is estimated that cysteine sulfoxides (alliins) and non-volatile $\gamma$-glutamylcysteine peptides represent more than $82 \%$ of the total content of sulphur in wild garlic. It was also proven that allicin one of the main components of Allium ursinum - has high antifungal activity (Bagiu et al., 2012; Pârvu et al., 2011). In the studies by Dżugan et al. (2014), it was found that the freeze-drying process did not cause a significant decrease in the antibacterial and antifungal activities of the wild garlic extract compared to fresh leaves. On the other hand, Bagiu et al. (2012) finds that fresh leaves contain $0.25-1.15 \%$ of alliin, while contain dried leaves $0.7-1.7 \%$ of alliin. Therefore, in the tests conducted, the addition of $1 \%$ of freeze-dried garlic slowed down the milk fermentation process, which resulted in the reported differences in $\mathrm{pH}$ and titratable acidity between the control kefir and kefir with wild garlic.

Wild garlic leaves contain flavonoids, chlorophylls and carotenoids, which give it its green colour (Štajner et al., 2008). The leaves of wild garlic have a high content of pigments: chlorophyll A2 $2.87 \pm 0.03 \mathrm{mg} / \mathrm{g}$ of chlorophyll B $1.35 \pm 0.01 \mathrm{mg} / \mathrm{g}$ and $9.99 \pm 0.01 \mathrm{mg} / \mathrm{g}$ of carotenoids (Sobolewska et al., 2015; Štajner and Szöllősi Varga, 2003). Therefore, the addition of wild garlic to kefir significantly changed the components of colours $L^{*}, a^{*}$ and $b^{*}$ in kefir from sheep's milk (Table 2). A darkening of colour and an increase in the proportion of green and yellow colours was found in kefir with wild garlic powder compared to the control.

The addition of freeze-dried wild garlic significantly reduced syneresis of kefir from sheep's milk (Table 2). The addition of $1 \%$ of garlic powder reduces the adverse effect of syneresis by approx. $3 \%$, which was probably the effect of rehydration of wild garlic. Vivar-Quintana et al. (2006) showed that syneresis in yogurts from sheep's milk depends on the somatic cell count (SCC) in the sheep's milk used for their production. Syneresis defined there as the volume of serum that was not retained within the structure on centrifugation was in the range from $1 \mathrm{ml}$ when the SCC in milk was less than $500000 / \mathrm{ml}$ and significantly increased with a higher SCC content in the milk.

Table 2. The colour ( $\left.\mathrm{L}^{*}, \mathrm{a}^{*}, \mathrm{~b}^{*}\right)$, lactic acid content, syneresis of natural sheep kefirs and with wild garlic

\begin{tabular}{lcc}
\hline \multicolumn{1}{c}{ Properties } & Control & $\begin{array}{c}\text { Enriched with 1\% } \\
\text { of wild garlic }\end{array}$ \\
\hline $\mathrm{pH}$ & $4.47^{\mathrm{a}} \pm 0.05$ & $4.58^{\mathrm{b}} \pm 0.04$ \\
Lactic acid, \% & $1.19^{\mathrm{a}} \pm 0.01$ & $1.06^{\mathrm{b}} \pm 0.01$ \\
Colour & & \\
$\quad \mathrm{L}^{*}$ & $91.44^{\mathrm{a}} \pm 1.40$ & $57.48^{\mathrm{b}} \pm 1.21$ \\
$\mathrm{a}^{*}$ & $-4.17^{\mathrm{a}} \pm 0.10$ & $-16.45^{\mathrm{b}} \pm 0.19$ \\
$\mathrm{~b}^{*}$ & $5.82^{\mathrm{a}} \pm 0.42$ & $12.08^{\mathrm{b}} \pm 0.25$ \\
Syneresis, \% & $23.26^{\mathrm{a}} \pm 1.20$ & $20.14^{\mathrm{b}} \pm 1.14$ \\
\hline
\end{tabular}

Values are means \pm standard deviation.

Means with different letters within the same row (a-b) are significantly different at $p \leq 0.05, \mathrm{~L} *$ represents the lightness (from 0 - black to 100 - white); $\mathrm{a}^{*}$ and $-\mathrm{a}^{*}$ redness and greenness, respectively; and $b^{*}$ and $-b^{*}$ yellowness and blueness, respectively.

Analyzing the texturometric profile (Table 3) of sheep's kefir with wild garlic, a significant increase was found in hardness [N], gumminess [N] and chewiness $[\mathrm{mJ}]$ compared to the results obtained for the control kefir $(p \leq 0.05)$. The addition of wild garlic caused 
Table 3. Texturometric profile (TPA test) of kefirs from sheep's milk

\begin{tabular}{lcc}
\hline \multicolumn{1}{c}{ Texture } & Control & $\begin{array}{c}\text { Enriched with 1\% } \\
\text { of wild garlic }\end{array}$ \\
\hline Hardness, N & $0.27^{\mathrm{a}} \pm 0.12$ & $0.77^{\mathrm{b}} \pm 0.32$ \\
Adhesiveness, mJ & $0.14^{\mathrm{a}} \pm 0.02$ & $0.20^{\mathrm{a}} \pm 0.10$ \\
Resilience & $0.93^{\mathrm{a}} \pm 0.04$ & $0.21^{\mathrm{b}} \pm 0.02$ \\
Stringiness length, mm & $1.72^{\mathrm{a}} \pm 0.77$ & $2.23^{\mathrm{a}} \pm 1.11$ \\
Cohesiveness & $0.95^{\mathrm{a}} \pm 0.05$ & $0.55^{\mathrm{b}} \pm 0.02$ \\
Springiness, mm & $14.49^{\mathrm{a}} \pm 0.55$ & $15.81^{\mathrm{a}} \pm 1.59$ \\
Gumminess, N & $0.26^{\mathrm{a}} \pm 0.09$ & $0.42^{\mathrm{b}} \pm 0.11$ \\
Chewiness, mJ & $3.84^{\mathrm{a}} \pm 0.34$ & $7.08^{\mathrm{b}} \pm 2.42$ \\
\hline
\end{tabular}

Values are means \pm standard deviation.

Means with different letters within the same row $(\mathrm{a}-\mathrm{b})$ are significantly different at $p \leq 0.05$.

a decrease in the resilience and cohesiveness of kefirs. The hardness of fermented sheep's milks was studied by Bonczar et al. (2002), Bonczar and Reguła (2003), Vivar-Quintana et al. (2006). The authors classified storage time, the amount of starter cultures added and the content of somatic cells in sheep's milk to the factors influencing hardness. Glibowski and Kowalska's (2012) studies indicated that the texture of kefirs can be shaped by the addition of inulin.

Table 4 shows the results of sensory characteristics and preferences for the sheep's kefirs. The results of the ranking test showed that natural kefir was more preferred than the one with wild garlic, although some people evaluated the kefir with wild garlic as appropriate.

In the opinion of the evaluators, the addition of wild garlic significantly reduced the intensity of sour taste, which could be the result of the lower lactic acid content. Furthermore, the taste of garlic was evaluated as intense. The green colour of the kefirs was assessed as not very distinctive in comparison to the white colour of natural kefirs. Moreover, a more solid and characteristic consistency was indicated in kefirs with garlic than in the controls. The sensory analysis confirmed the results of the TPA test that the consistency of kefir with wild garlic was more solid compared to
Table 4. Sensory properties of sheep kefirs, $n=12$

\begin{tabular}{lcc}
\hline \multicolumn{1}{c}{ Properties } & Control & $\begin{array}{c}\text { Enriched with } 1 \% \\
\text { of wild garlic }\end{array}$ \\
\hline Preferences & $0.61^{\mathrm{a}} \pm 0.25$ & $0.86^{\mathrm{a}} \pm 0.41$ \\
Consistency & $2.94^{\mathrm{a}} \pm 1.66$ & $5.11^{\mathrm{b}} \pm 1.03$ \\
$\mathrm{CO}_{2}$ saturation & $2.22^{\mathrm{a}} \pm 1.96$ & $3.17^{\mathrm{a}} \pm 1.58$ \\
Colour & $6.39^{\mathrm{a}} \pm 0.72$ & $4.06^{\mathrm{b}} \pm 1.04$ \\
Yeasty taste & $2.56^{\mathrm{a}} \pm 1.72$ & $2.50^{\mathrm{a}} \pm 1,69$ \\
Sour taste & $5.28^{\mathrm{a}} \pm 0.27$ & $4.11^{\mathrm{b}} \pm 0.49$ \\
Garlic taste & $0.00^{\mathrm{a}} \pm 0.01$ & $6.33^{\mathrm{b}} \pm 1.68$ \\
Off-flavours & $0.50^{\mathrm{a}} \pm 0.18$ & $0.84^{\mathrm{a}} \pm 0.41$ \\
Sour aroma & $3.33^{\mathrm{a}} \pm 1.94$ & $3.94^{\mathrm{a}} \pm 1.80$ \\
- of fermentation & & $1.46^{\mathrm{a}} \pm 0.01$ \\
Strange aroma & $1.44^{\mathrm{a}} \pm 0.28$ & $7.17^{\mathrm{b}} \pm 1.26$ \\
Aroma of garlic & $0.11^{\mathrm{a}} \pm 0.07$ &
\end{tabular}

Values are means \pm standard deviation. Means with different letters within the same row $(\mathrm{a}-\mathrm{b})$ are significantly different at $p \leq 0.05$.

natural ones. No significant effect of the addition of wild garlic was found on saturation with $\mathrm{CO}_{2}$, yeasty taste or off-favours and on aroma: sour-fermentation and strange. The studies by Cais-Sokolińska et al. (2008) indicate that the taste and aroma of kefirs from sheep's milk can also be modified by the selection of starter cultures.

\section{CONCLUSIONS}

Wild garlic can be used as a valuable supplement and taste and flavour modifier in the production of kefirs from sheep's milk. The addition of $1 \%$ of freeze-dried garlic slowed down the fermentation process, changed the colour and reduced the syneresis of kefirs. The addition of wild garlic to kefirs increased hardness and determined most of its sensory qualities.

\section{REFERENCES}

Alexopoulos, A., Tzatzimakis, G., Bezirtzoglou, E., Plessas, S., Stavropoulou, E., Sinapis, E., Abas, Z. (2011). Microbiological quality and related factors of sheep 
milk produced in farms of NE Greece. Anaerobe, 17, 6, 276-279.

Bagiu, R., Vlaicu, B., Butnariu, M. (2012). Chemical composition and in vitro antifungal activity screening of the Allium ursinum L. (Liliaceae). Int. J. Mol. Sci., 13, 2, 1426-1436. http://dx.doi.org/10.3390/ijms13021426

Baryłko-Pikielna, N., Matuszewska, I. (2014). Sensoryczne badania żywności [Sensory testing of food]. Podstawy. Metody. Zastosowania. Warszawa: Wyd. Nauk. PTTŻ [in Polish].

Bat-Chen, W., Golan, T., Peri, I., Ludmer, Z., Schwartz, B. (2010). Allicin purified from fresh garlic cloves induces apoptosis in colon cancer cells via Nrf2. Nutr. Cancer, 62, 7, 947-57. http://dx.doi.org/10.1080/01635581.201 0.509837

Bonczar, G., Wszołek, M. (1997). Jakość i trwałość kefiru i jogurtu produkowanego $\mathrm{z}$ mleka owczego [The quality and durability of kefir and yogurt made from sheep's milk]. Żywn. Nauka Technol. Jakość, 10, 1, 61-68 [in Polish].

Bonczar, G., Regula, A. (2003). The influence of different amount of starter culture on the properties of yogurts obtained from ewe's milk. EJPAU, Ser. Food Sci. Techn., 6(2). Retrieved from http://www.ejpau.media.pl/volume6/issue2/food/art-04.html

Bonczar, G., Reguła-Sardat, A., Pustkowiak, H., Żebrowska, A. (2009). Wpływ substytucji mleka owczego mlekiem krowim na właściwości bundzu [Effect of mixing of ewe's and cow's milk on bundz cheese properties]. Żywn. Nauka Technol. Jakość, 5, 66, 96-106 [in Polish].

Bonczar, G., Wszołek, M. Siuta, A. (2002). The effects of certain factors on the properties of yoghurt made from ewe's milk. Food Chem., 79, 1, 85-91. http://dx.doi. org/10.1016/S0308-8146(02)00182-6

Bonczar, G., Wszołek, M., Serafin, M., Prażuch, T. (1995). Wpływ jakości mleka owczego na wyprodukowany $\mathrm{z}$ niego jogurt [The impact of quality of sheep's milk on yogurt made from it]. Zesz. Nauk. AR Krak. 308, Technol. Żywn., 7, 15-21 [in Polish].

Bytyqi, H., Mehmeti, H., Vehapi, I., Rrustemaj, F., Mehmeti, I. (2013). Effect of bacterial content and somatic cell count on sheep milk quality in Kosovo. Food Nutr. Sci., 4, 414-419. http://dx.doi.org/10.4236/fns.2013.44053

Cais-Sokolińska, D., Danków, R., Pikul, J. (2008). Physicochemical and sensory characteristics of sheep kefir during storage. Acta Sci. Pol., Technol. Aliment., 7, 2, 63-73.

Commission Regulation (EC) No 853/2004 of the European Parliament and of the Council of 29 April 2004 laying down specific hygiene rules for food of animal origin. (2004).

Danków, R., Wójtowski, J., Gut, A., (2000). Wpływ kultur starterowych i czasu przechowywania na cechy jakościowe kefiru z mleka owczego [The influence of starter cultures and storage time on the quality features of kefir from sheep's milk]. Zesz. Nauk. AR Wroc. 399, Konf., 30, 135-142 [in Polish].

Danków, R., Pikul J., (2011). Przydatność technologiczna mleka owczego do przetwórstwa [Technological suitability of sheep milk for processing]. Nauka Przyr. Technol., 5, 2 [in Polish].

Durak, I., Kavutcu, M., Ayta, B. (2004). Effects of garlic extract consumption on blood lipid and oxidant/ antioxidant parameters in humans with high blood cholesterol. J. Nutr. Bioch., 15, 373-377. http://dx.doi.org/10.1016/j. jnutbio.2004.01.005

Dżugan, M., Kordiaka, R., Kačániová, M., Wesołowska, M. (2014). Czosnek niedźwiedzi (Allium ursinum) jako uzupełnienie wiosennej diety [Wild garlic (Allium ursinum) as a supplement to the spring diet]. Właściwości produktów i surowców żywnościowych. Wybrane zagadnienia (pp. 248-258). Kraków: Oddz. Małopolski PTTŻ, Uniw. Roln. [in Polish].

Glibowski, P., Kowalska, A. (2012). Rheological, texture and sensory properties of kefir with high performance and native inulin. J. Food Eng., 111, 299-304. http:// dx.doi.org/10.1016/j.jfoodeng.2012.02.019

Katsiari, M. C., Voutsinas, L. P., Kondyli E. (2002). Manufacture of yogurt from stored frozen sheep's milk. Food Chem., 77, 4, 413-420. http://dx.doi.org/10.1016/ S0308-8146(01)00367-3

Králíčková, Š., Pokorná, M., Kuchtík, J. Filipčík, R. (2012). Effect of parity and stage of lactation on milk yield, composition and quality of organic sheep milk. Acta Universitatis Agriculturae Et Silviculturae Mendelianae Brunensis, 9, 1, 71-78. https://doi.org/10.11118/ actaun201260010071

Litwińczuk, Z. (2011). Metody oceny towaroznawczej surowców i produktów zwierzęcych [Evaluation of animal raw material and animal foodstuffs]. Lublin: Wyd. UP [in Polish].

Pârvu, M., Pârvu, A., Vlase, L., Rosca-Casian, O., Pârvu, O. (2011). Antifungal properties of Allium ursinum L. Ethanol extract. J. Med. Plants Res., 5, 10, 2041-2046.

PN-ISO 11035:1999 Analiza sensoryczna - Identyfikacja i wybór deskryptorów do ustalania profilu sensorycznego $\mathrm{z}$ użyciem metod wielowymiarowych [Sensory analysis - identification and selection of descriptors for 
establishing a sensory profile using multivariate methods] [in Polish].

Radulović, N. S., Miltojević, A. B., Stojković, M. B., Blagojević, P. D. (2015). New volatile sulfur-containing compounds from wild garlic (Allium ursinum L., Liliaceae). Food Res. Int., 78, 1-10. http://dx.doi. org/10.1016/j.foodres.2015.11.019

Şahan, N., Say, D., Kaçar, A. (2005). Changes in chemical and mineral contents of Awassi ewes ' milk during lactation. Turk. J. Vet. Anim. Sci., 29, 3, 589-593.

Sapunjieva, T., Alexieva, I., Mihaylova, D., Popova, A. (2012). Antimicrobial and antioxidant activity of extracts of Allium ursinum L. J. BioSci. Biotechn., Special Edition, 143-145.

Sobolewska, D., Podolak, I., Makowska-Wąs, J. (2015). Allium ursinum: botanical, phytochemical and pharmacological overview. J. Phytochem Rev., 14, 1, 81-97. http://dx.doi.org/10.1007/s11101-013-9334-0

Štajner, D., Popović, B., Čanadanović-Brunet, J., Štajner, M. (2008). Antioxidant and scavenger activities of
Allium ursinum. Fitoterapia, 79, 303-305. http://dx.doi. org/10.1016/j.fitote.2007.01.008

Štajner, D., Szöllősi Varga, I. (2003). An evaluation of the antioxidant abilities of Allium species. Acta Biol. Szeged., 47, 1-4, 103-106.

Vivar-Quintana, A. M., Beneitez De La Mano, E., Revilla, I. (2006). Relationship between somatic cell counts and the properties of yoghurt made from ewes' milk. Int. Dairy J., 16,3, 262-267. http://dx.doi.org/10.1016/j. idairyj.2005.03.006

Wójtowski, J., Danków, R., Skrzypek, R., Fahr, R. D. (2003). The fatty acid profile in kefirs from sheep, goat and cow milk. Milchwissenchaft, 58, 633-636.

Znamirowska, A., Szajnar, K., Pawlos, M., Kalicka, D. (2016). Ocena możliwości zastosowania chelatu aminokwasowego magnezu do wzbogacania jogurtu [Assessing possible applications of magnesium amino acid chelate to enrich yoghurt]. Żywn. Nauka Technol. Jakość, 4 (107), 80-91 [in Polish]. 